\title{
ИСПОЛЬЗОВАНИЕ МАТЕМАТИЧЕСКИХ МЕТОДОВ В ОЦЕНКЕ СОСТОЯНИЯ ЭКОСИСТЕМЫ ОЗЕРА ИМАНДРА ПО ДИАТОМОВЫМ КОМПЛЕКСАМ ДОННЫХ ОТЛОЖЕНИЙ
}

Вокуева С.И. ${ }^{1}$, Денисов Д.Б. ${ }^{2}$

https://doi.org/10.31241/MIEN.2018.14.16

${ }^{1}$ АФ МГТУ, Апатиты, Sonyavokueva23@mail.ru

${ }^{2}$ Институт проблем промышленной экологии Севера КНЦ РАН, denisow@inep.ksc.ru

\section{Аннотация}

Показаны возможности использования методов математической статистики (базовых и многомерных) для количественной обработки результатов диатомового анализа и данных химического состава вод и донных отложений озера Имандра, что позволило сделать выводы о современном экологическом состоянии различных участков акватории. Выявлены наиболее значимые гидрохимические факторы, определяющие развитие сообществ диатомей и их ответные реакции на антропогенное загрязнение. Представлены наиболее информативные количественные показатели качества вод водоема, рассчитанные по диатомовым комплексам, анализируются перспективы их использования для экологического зонирования вод с различным экологическим статусом.

\section{Summary}

The possibilities of mathematical statistics (basic and multivariate) methods using for quantitative estimation of diatom analysis results and data of the chemical composition of waters and bottom sediments of Imandra Lake have been shown and the current ecological states of various areas of the Lake area have been described. The most significant hydrochemical factors determining the development of diatom communities and their responses to anthropogenic pollution have been identified. The most informative quantitative indicators of the water quality of the Lake, calculated on diatom-infer models, are presented, and the prospects of their use for ecological zoning of the Imandra Lake are analyzed.

\section{Введение}

Решение экологических задач, в частности, анализ условий формирования качества вод и их влияния на гидробионтов, невозможна без использования базовых и многомерных исследующих методов математической статистики, позволяющих выявлять наиболее значимые факторы среды и оценивать достоверность обнаруженных закономерностей [14]. Одно их крупнейших озер на европейском северо-западе - Имандра испытывает долговременную многофакторную антропогенную нагрузку и является объектом экологических исследований ни одно десятилетие [1]. Целый ряд исследований был посвящен водорослевым сообществам водоема, как наиболее надежного и информативного биоиндикатора состояния водных экосистем $[3,6,7,8,16]$. В то же время, оценка качества вод оз. Имандра по гидробиологическим и гидрохимическим показателям затруднена в силу практической невозможности синхронизировать время отбора проб в различных 
участках акватории. Сравнительно короткое «гидробиологическое лето» в условиях субарктики определяет значительную вариативность гидробиологических показателей, что особенно ярко проявляется в сообществах фитопланктона. Поэтому в качестве основного индикатора условий формирования качества вод и состояния экосистемы были использованы диатомовые комплексы (ДК) поверхностных слоев донных отложений (ДО), содержащие интегральную информацию о видовом составе и структуре сообществ диатомовых сообществ за последние годы, что позволило корректно провести сравнительный анализ состояния водной среды в различных участках акватории.

\section{Материалы и методы}

Оз. Имандра характеризуется высокой степенью развития береговой линии и состоит из трёх в значительной степени обособленных плёсов: Большой (БолИ), Йокостровской (ЙИ) и Бабинской Имандры (БИ) (рис. 1). Сравнительная изолированность отдельных участков акватории, плесов, заливов

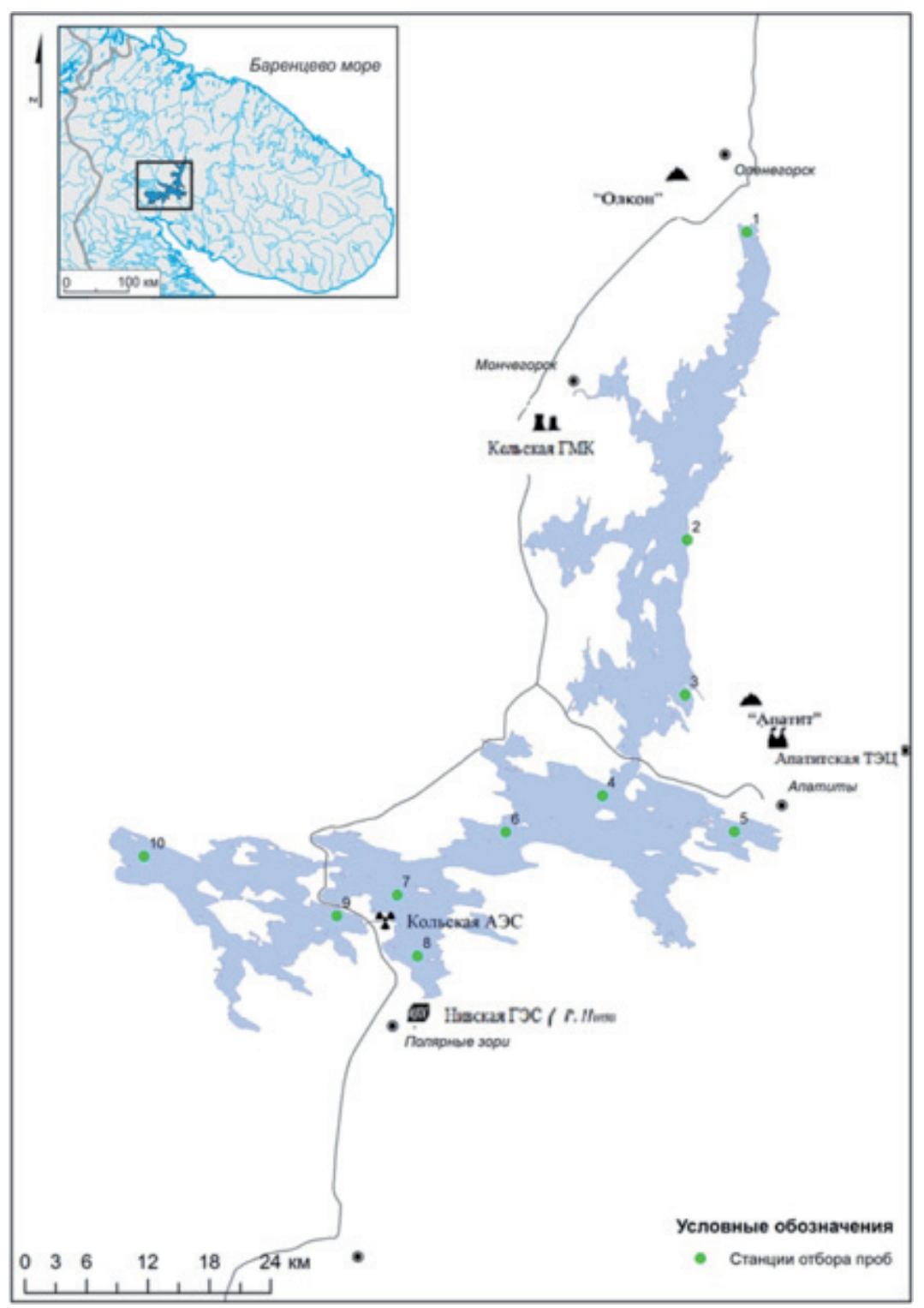

Рис. 1. Карта-схема оз. Имандра и расположение станций отбора проб. 
и губ обуславливает гидрохимическую и гидробиологическую неоднородность вод озера [1].

Материалом для анализа послужили ДК из поверхностных (0-1 см) слоев ДО различных участков акватории оз. Имандра (рис. 1). Отбор проб и их анализ был выполнен стандартными общепринятыми методами $[4,5]$, с изменениями, разработанными в ИППЭС КНЦ РАН, описанными ранее $[3,9]$. Химический анализ вод и ДО был выполнен в аналитической лаборатории ИППЭС КНЦ РАН согласно методике [13, 23].

На основе видового состава и структуры ДК были рассчитаны индекс сапробности $[2,15]$ и значение $\mathrm{pH}$, вычисленное методом авторов [10]. Таксономическое разнообразие оценивалось индексом Шеннона-Уивера $\left(\mathrm{H}^{\prime}\right)$ и обратным индексом Симпсона (1/D) [21, 22].

Результаты диатомового анализа сопоставлялись со средними гидрохимическими показателями вод озера Имандра за 3 года (2011-2013 гг.) и средним содержанием химических элементов в ДО, в первую очередь, с концентрациями приоритетных загрязнителей. Для оценки степени связи показателей ДК и факторов среды использован корреляционный анализ; достоверность выявленных закономерностей оценивалась по коэффициенту детерминации $\mathrm{r}^{2}$.

Сходство таксономического состава ДК между станциями отбора проб оценивались по качественным и количественным признакам с помощью ряда флористических коэффициентов Жаккара (1), Дайса (2), СеренсенаЧекановского (3) и Шимкевича-Симпсона (4) [17, 18, 19, 20, 24]:

$$
\begin{aligned}
& K_{j}=\frac{c}{(a+b+c)} \\
& K_{D}=\frac{[c-\min (a, b)]}{[c+\min (a, b)]} \\
& K_{S}=\frac{2 c}{(a+b)} \\
& K_{S h s}=\frac{c}{\min (a, b)}
\end{aligned}
$$

где $a$ - количество таксонов на первой станции отбора проб, $b$ - на второй станции, с - количество таксонов, общих для обеих станций.

Для иерархической классификации схожих по ДК станций был выполнен кластерный анализ по коэффициенту Жаккара. Расчет коэффициентов и построение дендритов было выполнено с помощью программного модуля «Graphs» [11].

Выявление регулирующих развитие диатомовых сообществ факторов и поиск различий в условиях формирования качества вод в различных участках акватории оз. Имандра осуществлялось с помощью метода главных компонент (РСА) в двумерном факторном пространстве на основе корреляционной матрицы $[12,14]$. 


\section{Результаты и обсуждение}

Информационно-энтропийный индекс Шеннона-Уивера ДК в ДО различных участков акватории оз. Имандра характеризуется значительной вариабельностью (от 2.7 до 4.5 бит/экз.), что свидетельствует о широком спектре условий для развития водорослей (рис. 2). Наибольшие значение индекса были зафиксированы в сравнительно изолированных участках акватории
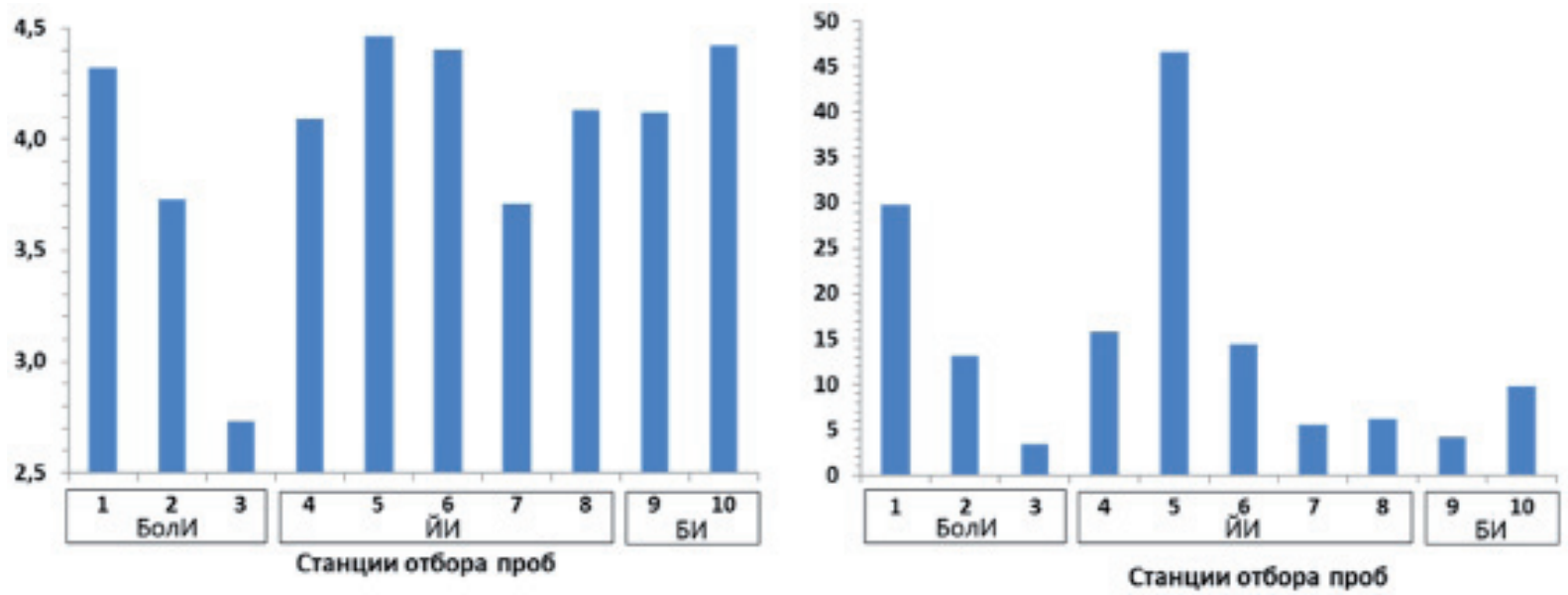

Рис. 2. Значения индексов $H^{\prime}$ (слева) и 1/D (справа) в ДК ДО различных участков акватории оз. Имандра.

(станции $1,5,10)$ и зонах смешивания водных масс, отличающихся по гидрохимическим показателям (рис. 1, 2). Более показательным для анализа таксономического разнообразия оказался обратный индекс доминирования (или индекс полидоминантности) Симпсона, позволяющий выделить наиболее значимые отличия в составе и структуре ДК в силу высокой чувстви-

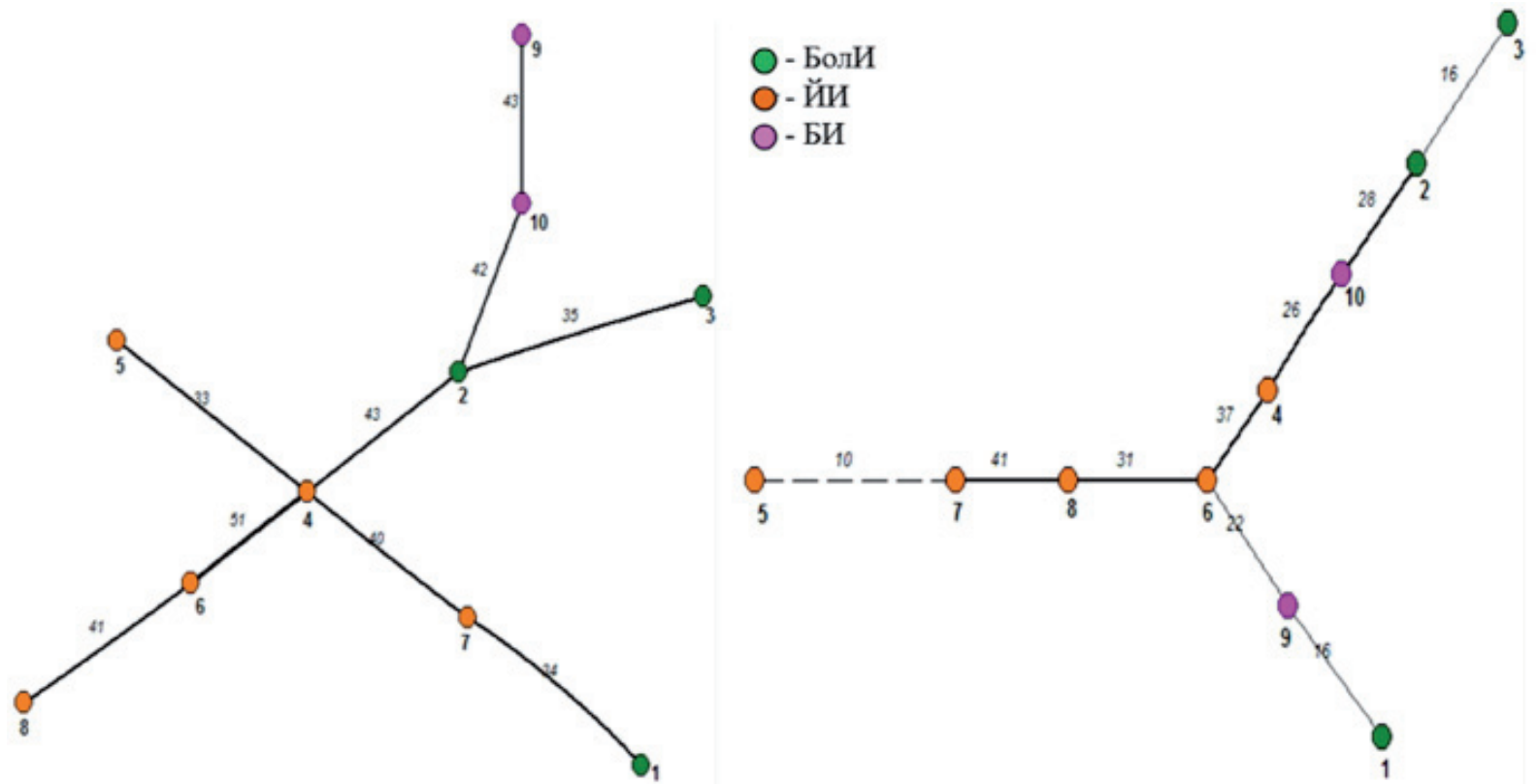

Рис. 3. Дендриты таксономического сходства ДК поверхностных ДО в различных участках акватории оз. Имандра на основе коэффиииентов Жаккара (справа) и Дайса (слева). 


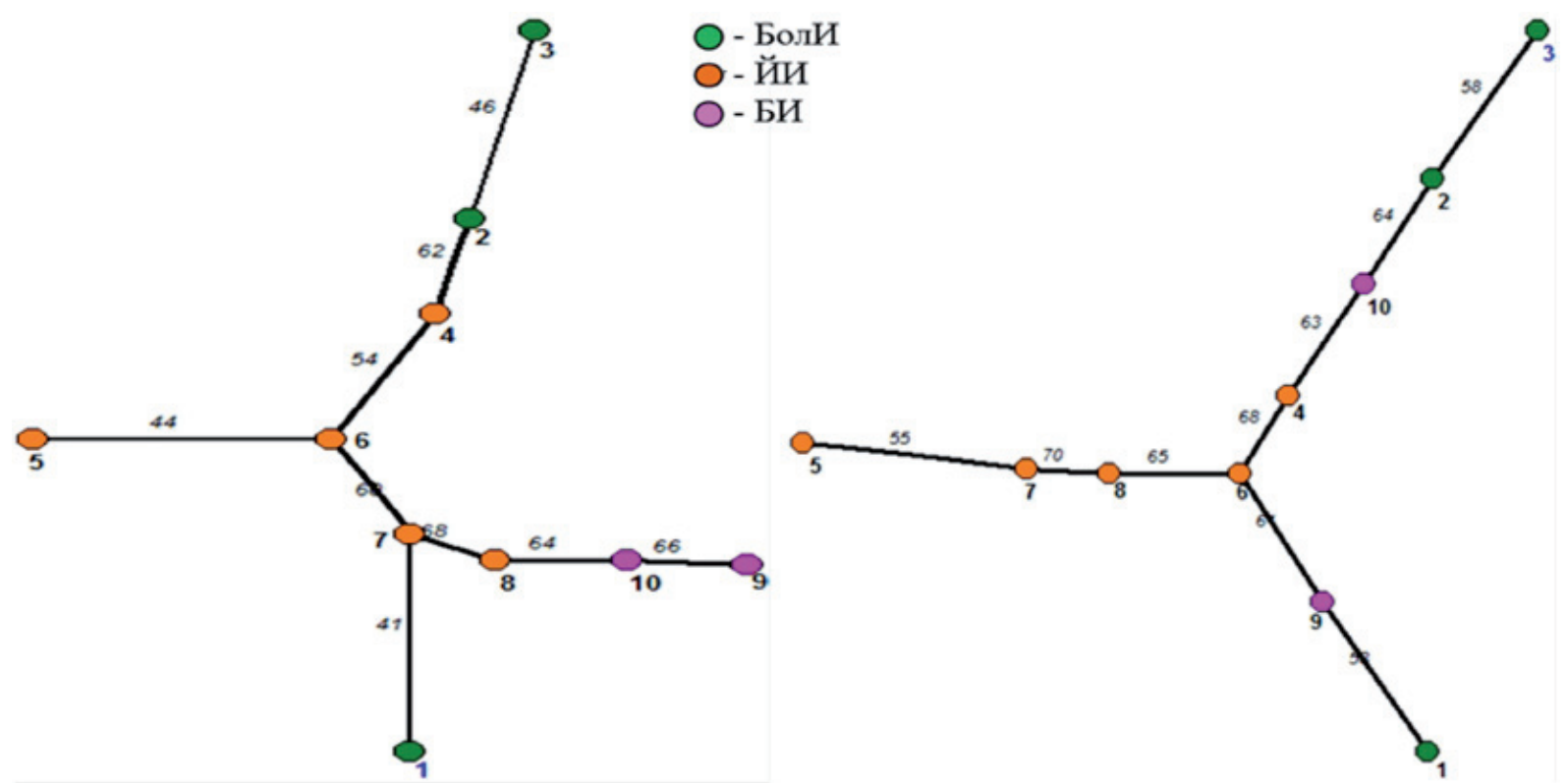

Рис. 4. Дендриты таксономического сходства ДК поверхностных ДО в различных участках акватории оз. Имандра на основе коэффичиентов СеренсенаЧекановского (слева) и Шимкевича-Симпсона (справа).

тельности к динамике количественных показателей массовых видов. Самые высокие значения 1/D были зафиксированы на станциях 1 - мелководный залив Тик-Губа, где высокое разнообразие диатомей определяется наличием большого количества разнообразных донных форм и обрастателей, и станции 1 - губа Куреньга, где значительный вклад в ДК вносят речные виды.

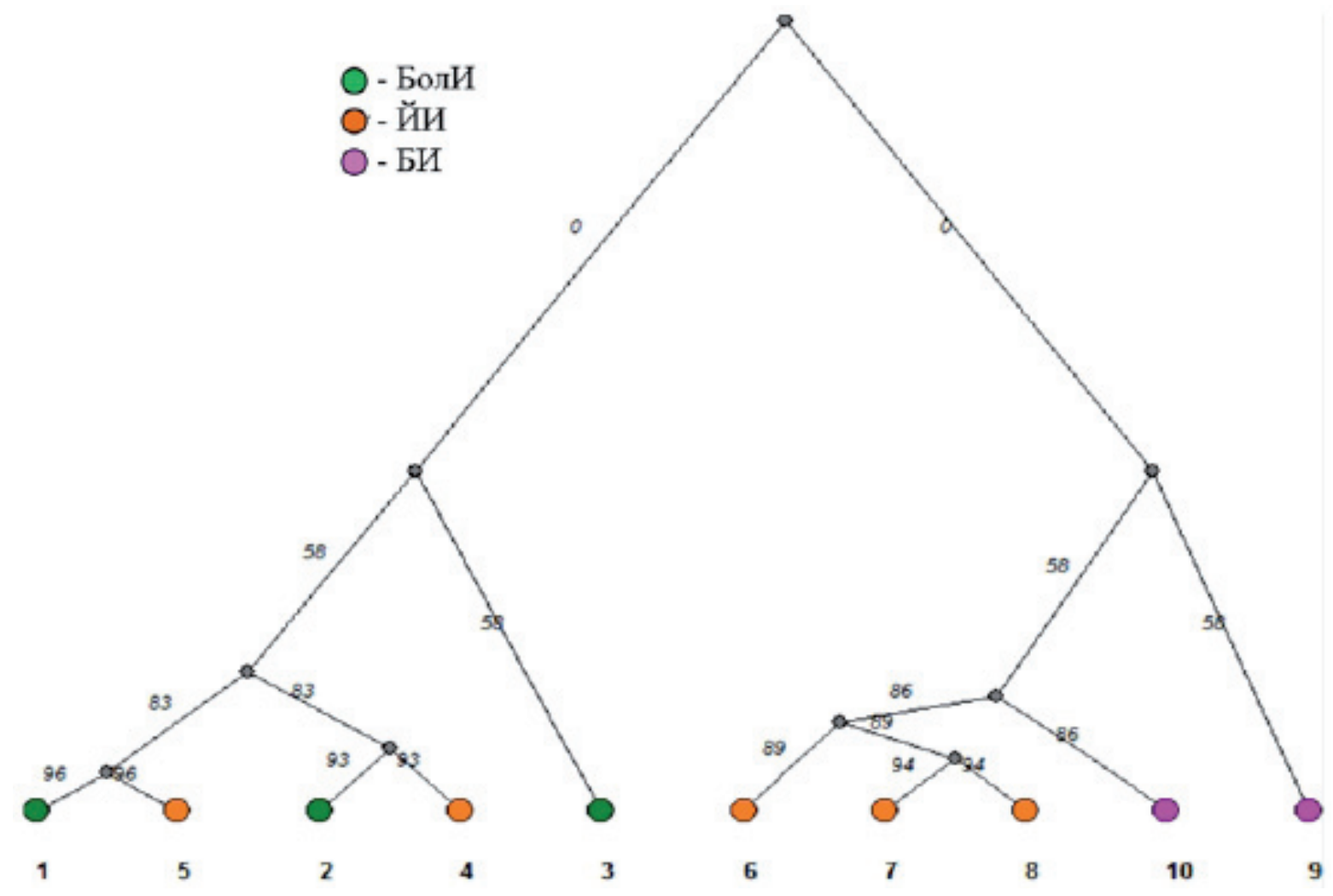

Рис. 5. Кластерный анализ флористического сходства ДК поверхностных ДО в различных участках акватории оз. Имандра на основе коэф. Жаккара. 

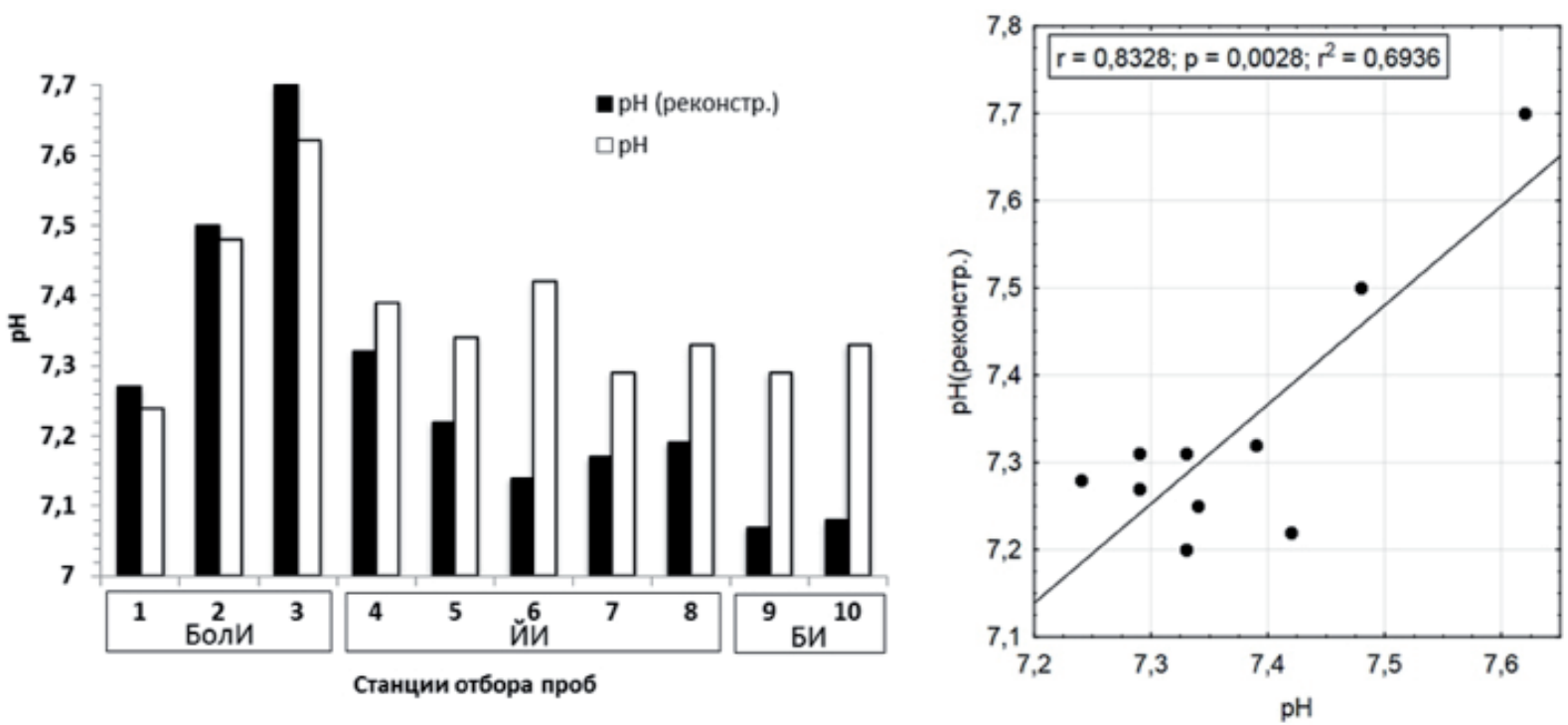

Рис. 6. Значения рН реконструированные по ДК ДО в сравнении с усредненными результатами измерений рН водь (2011-2013 г2.).

Различия в таксономическом составе ДК наглядно демонстрируют разницу в экологических условиях в различных участках акватории (рис. 3).

Так, наиболее сходными оказались станции 4 и 6, находящиеся в северной и центральной части ЙИ. Высокое сходство также характерно для станций 7 и 8 (южная часть ЙИ), 9 и 10 (БИ), а также 2 и 3 (центральная и южная часть БолИ). Наибольшие отличия в таксономическом составе ДК были отмечены для сравнительно изолированных участков акватории - станции 1 (губа Куреньга) и 5 (Тик-губа). Эти же закономерности прослеживаются и по результатам количественного анализа сходства ДК, с учетом численности каждого вида (рис. 4).

Результаты кластерного анализа ДК поверхностных ДО в различных участках акватории оз. Имандра на основе коэффициента Жаккара позволяют разделить все станции на две большие группы, в одну из которых вошел плес БолИ, в другую - БИ. Станции центрального плеса - ЙИ оказались разделены между этими кластерами (рис. 5). Внутри этих групп выделяются наиболее трансформированные антропогенной деятельностью участки акватории - губа Белая, принимающая стоки апатитовой промышленности (станция 3), и губа Молочная, подверженная тепловому загрязнению Кольской АЭС (станция 9).

Вычисленные по ДК значения $\mathrm{pH}$ хорошо коррелируют с результатами измерений электродным рН-метром (рис. 6). Различия объясняются нерегулярностью и малым количеством гидрохимических отборов проб в некоторых станциях и значительной вариабельностью $\mathrm{pH}$ в течение сезона, в то время как расчет с помощью ДК позволяет получить интегральные, усредненные за последние несколько лет значения. Наибольшее значение водородного показателя (7.7) наблюдается в южной части БолИ (станция 3), в районе губы Белой (рис. 6). Наименьшие значения рН наблюдались в плесе БИ. 

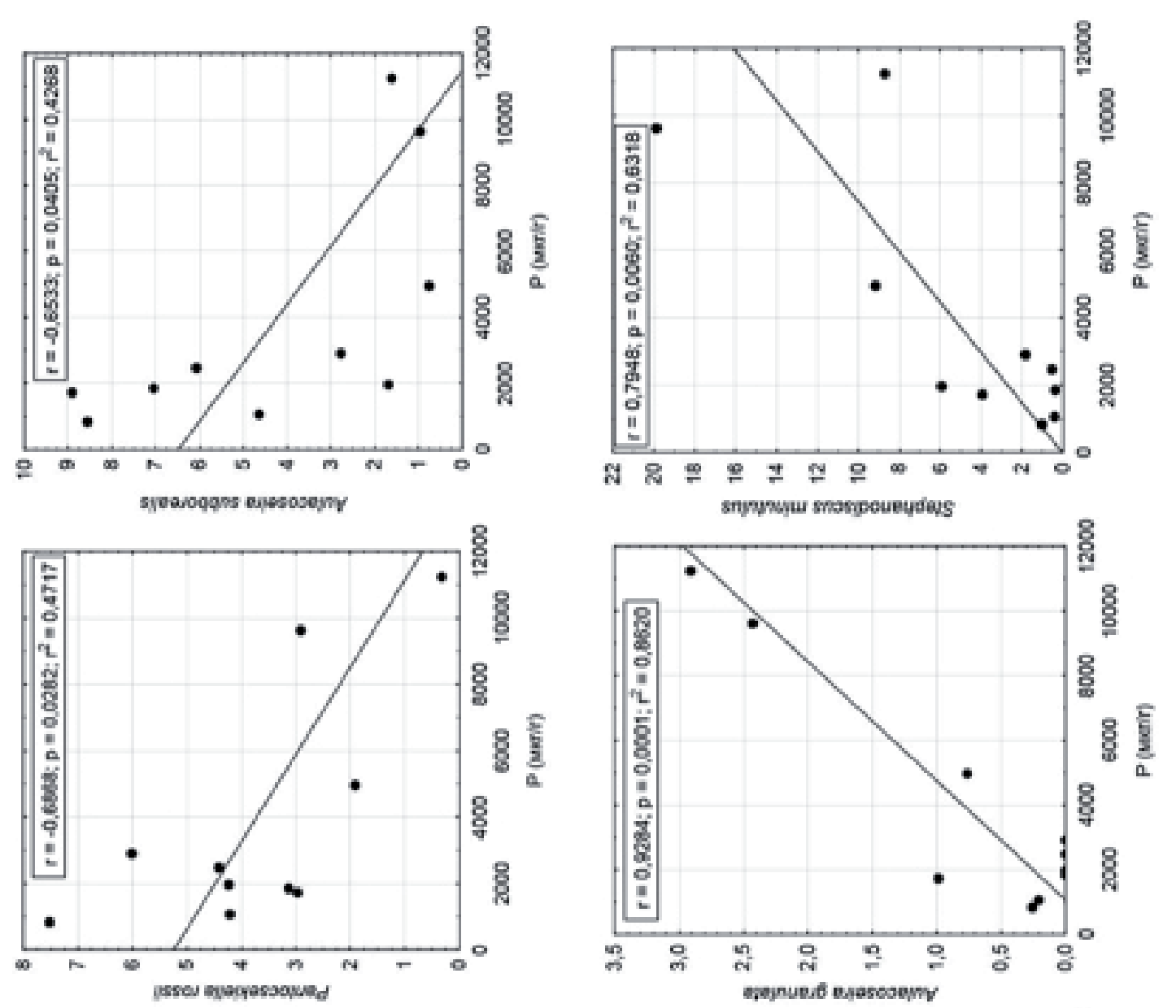

8
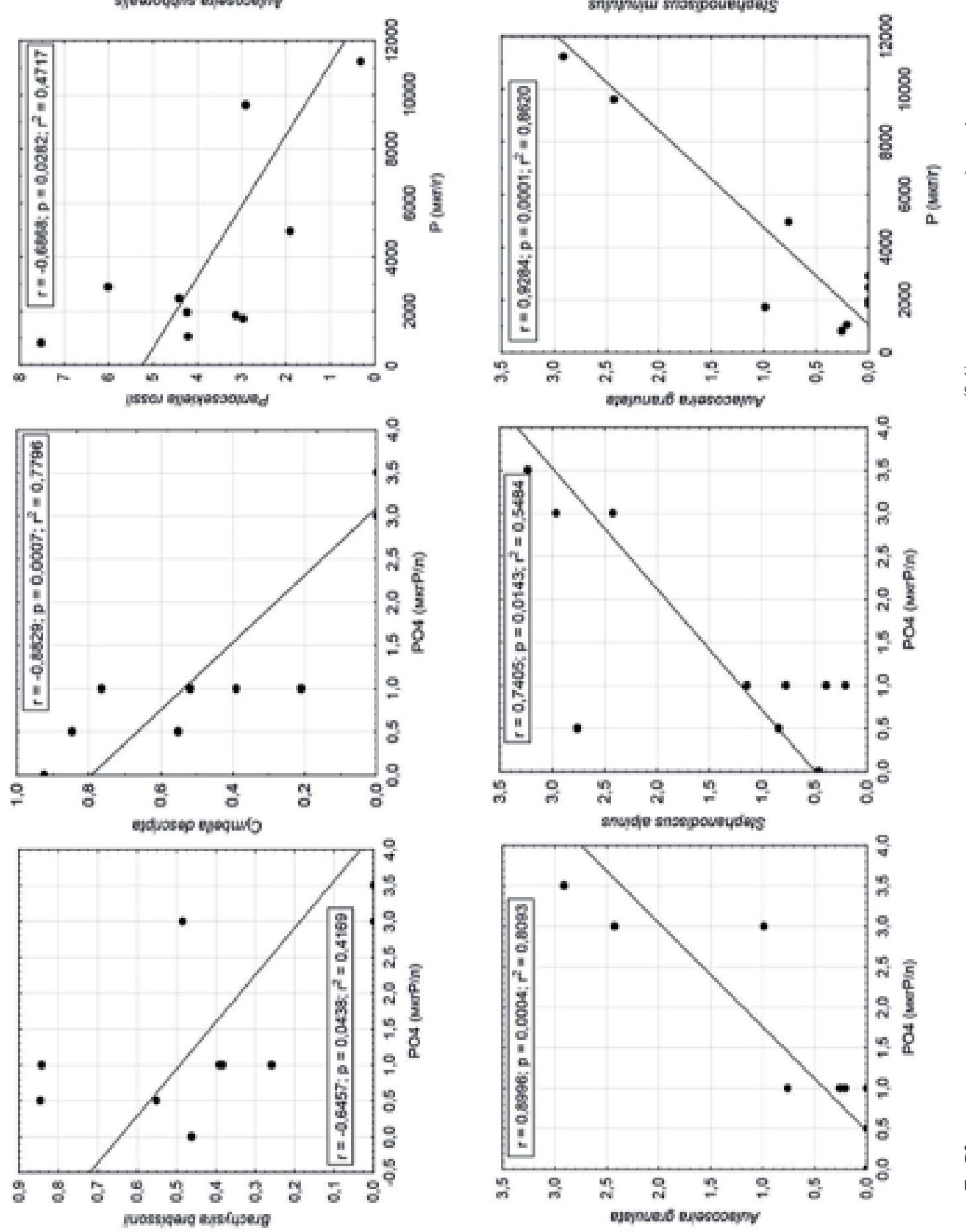

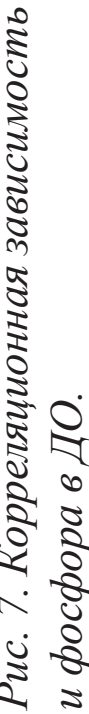



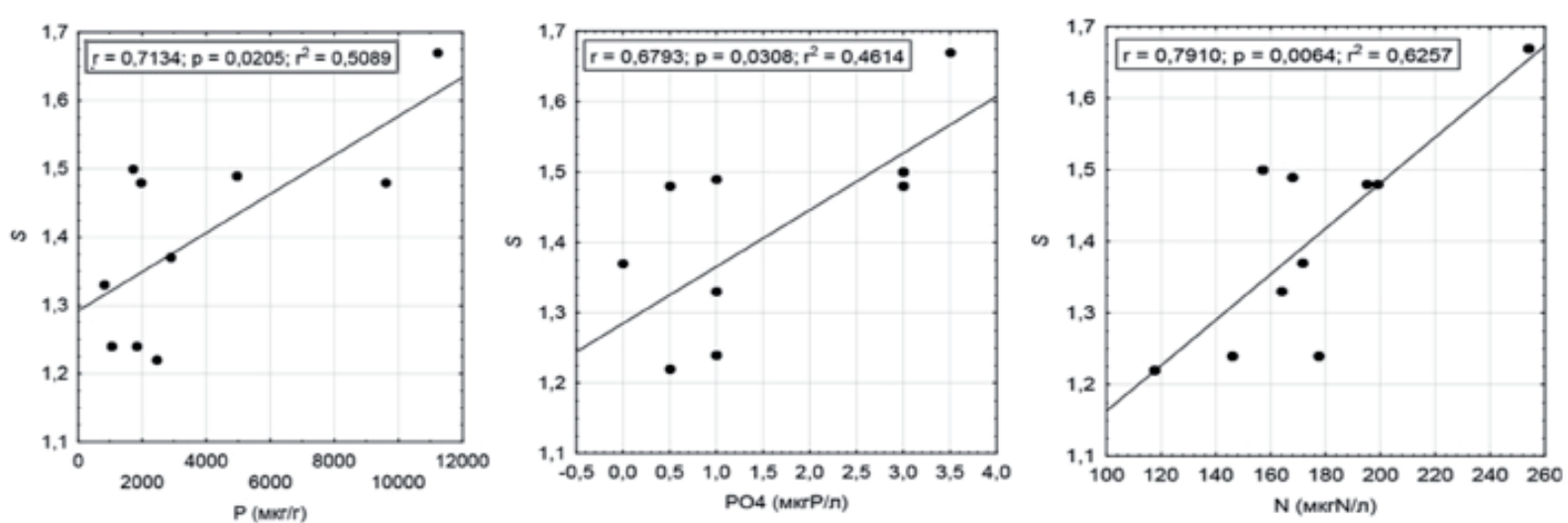

Рис. 8. Корреляциионная зависимость индекса сапробности (S) рассчитанного по ДК поверхностных ДО оз. Имандра от содержания фосфатов в воде и фосфора в ДО.

Результаты корреляционного анализа показали достоверную зависимость численности некоторых массовых видов диатомей, а также видов индикаторов экологических условий от содержания биогенных элементов - фосфатов в воде и фосфора в донных отложениях (рис. 7). Так, были выделены виды диатомей развивающиеся в условиях повышенных содержаний биогенных элементов (положительный коэффициент корреляции), а также наоборот, предпочитающие минимальные концентрации (отрицательный коэффициент корреляции). Эти данные могут быть использованы для биоиндикации качества вод в условиях фосфорной нагрузки и демонстрируют потенциал использования ДК поверхностных ДО для интегральной экологической оценки водных экосистем.

Достоверная положительная зависимость была выявлена между индексом сапробности $(S)$, рассчитанного по показателям ДК и содержанием фосфатов в ДО и фосфора и азота в воде (рис. 8). Индекса сапробности отража-
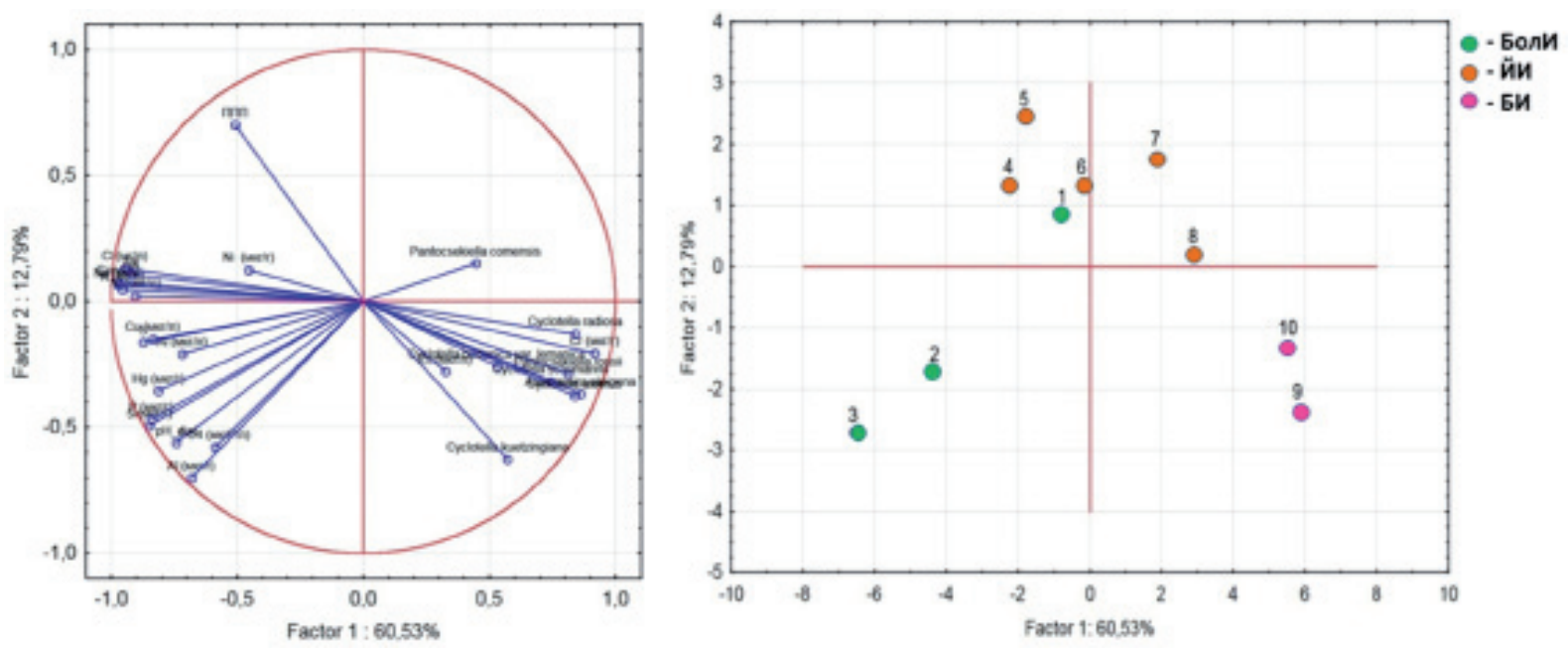

Pис. 9. Результать РСА: взаимосвязь относительной численности (\%) индикаторных и массовых видов диатомей, индекса сапробности (S) и содержания элементов - загрязнителей и биогенных веществ в воде и донных отложениях $(\mathrm{Cu}, \mathrm{Ni}$, $\mathrm{Hg}, \mathrm{P}, \mathrm{PO} 4, \mathrm{SO} 4, \mathrm{Al}, \mathrm{Sr}, \mathrm{Cl}, \mathrm{Na}, \mathrm{K}, \mathrm{pH}$, щелочность, потери при прокаливании (\%)) в пространстве двух факторов для различных участков акватории оз. Имандра. 
ет наличие органического загрязнения и выступает косвенным показателем трофического статуса водоёма.

Результаты многомерного статистического исследования методом главных компонент (РСА) позволил выявить основные факторы, определяющие развитие диатомовых водорослей и произвести классификацию участков акватории озера, различающихся условиями формирования качества вод (рис. 9). Первый фактор, объясняющий $60.5 \%$ общей дисперсии, составлен наиболее значимыми для диатомей биогенными элементами (соединения азота и фосфора), а также, щелочностью, электропроводностью и некоторыми токсичными элементами $(\mathrm{Cu}, \mathrm{Hg})$. С этим же пучков векторов сонаправлен индекс сапробности, отражающий биогенную нагрузку и характеризующийся отрицательной корреляционной связью с показателем численности диатомей, предпочитающих низкое содержание фосфора и азота. Таким образом, факторная модель отражает зависимость диатомей от элементов минерального питания (биогенных элементов) и токсичных веществ, ограничивающих их развитие. Второй, менее значимый фактор (12.8 \% общей дисперсии) составляют, преимущественно, потери при прокаливании (ППП, \%), отражающие условия седиментации в различных участках акватории: содержание органического вещества в ДО выше на тех станциях, где в меньшей степени накапливаются кремнеземные створки диатомовых водорослей.

На основе РСА исследованные станции были классифицированы согласно их расположению в двумерном факторном пространстве (рис. 9). Полученные результаты иллюстрируют различия в условиях обитания диатомей в исследованных участках акватории. Наибольшие различия характерны для плесов БолИ и БИ, плес ЙИ занимает промежуточное положение. Эти данные хорошо согласуются с результатами кластерного анализа (рис. 6) Максимальные различия в формировании качества среды в оз. Имандра были выявлены между станциями 3 (губа Белая) и 9 (губа Молочная). Диатомеи губы Белая развиваются в условиях интенсивной биогенной и токсической нагрузки, в то время как воды губы Молочная по своим гидрохимическим показателям близки к условно фоновым, и большое значение здесь, очевидно, имеет температурный фактор в связи с влиянием подогретых вод Кольской АЭС.

\section{Заключение}

ДК поверхностных ДО оз. Имандра характеризуются высоким таксономическим разнообразием, для оценки которого целесообразно использовать индекс полидоминантности Симпсона $(1 / \mathrm{D})$, позволяющий выделить участки акватории отличающиеся выраженностью доминирующих видов. На основе дендритов таксономического сходства ДК с использованием ряда качественных и количественных коэффициентов флористического сходства позволило выделить наиболее отличающиеся по условиям участки акватории оз. Имандра - залив Тик-Губа и губа Куреньга. Так называемое «флористическое ядро» ДК водоема сосредоточено в плесе ЙИ. Эти данные под- 
тверждаются результатами кластерного анализа на основе коэффициента качественного сходства Жаккара.

Результаты корреляционного анализа показали достоверную положительную связь относительной численности диатомей, предпочитающих высокое содержание биогенов (соединений фосфора), и отрицательную с видами, развивающимися в олиготрофных водах. На основе корреляционных зависимостей было показано, что индекс сапробности может быть использован для оценки антропогенной трансформации экосистемы озера Имандра в различных участках акватории.

Факторная модель на основе главных компонент (РСА) определила основные регулирующие развитие сообществ диатомей факторы - антропогенно обусловленную трансформацию качества вод связанную с токсическим загрязнением и эвтрофированием. В настоящее время в наибольшей степени трансформирована экосистема губы Белая. Условия, близкие к условно фоновым, сохраняются в плесе БИ, за исключение губы Молочная, испытывающей термическое загрязнение. Плес ЙИ занимает промежуточное положение, как зона смешивания вод плесов БолИ и БИ.

Полученные результаты могут быть использованы для оценки современного состояния экосистем и экологического зонирования акватории оз. Имандра в зависимости от степени антропогенных преобразований различных участков акватории.

\section{Список литературы}

1. Моисеенко Т.И., Даувальтер В.А., Лукин А.А. и др. Антропогенные модификации экосистемы озера Имандра. М: Наука, 2002. 403 с.

2. Баринова С.С., Медведева Л.А., Анисимова О.В. Биоразнообразие водорослей-индикаторов окружающей среды. Тель-Авив: PiliesStudio, 2006. -498 c.

3. Генкал С.И. Денисов Д.Б. Центрические диатомовые (Bacillariophyta) озера Имандра (Кольский п-ов) // Ботанический журнал, 2016. Т. 101. № 10. С. 1133-1144.

4. Давыдова Н. Н. Диатомовые водоросли - индикаторы природных условий водоемов в голоцене. Л.: Наука, 1985. 244 с.

5. Диатомовый анализ. Л.: 1949. Кн. 1. 240 с.; кн. 2. 238 с.

6. Денисов Д.Б., Валькова С.А., Терентьев П.М., Сандимиров С.С., Вандыш О.И. Современное состояние экосистемы оз. Имандра в зоне влияния Кольской АЭС (Мурманская область) // Вода: химия и экология, 2017. № 6. C. 41-51.

7. Денисов Д.Б. Современное состояние водорослевых сообществ планктона в зоне влияния Кольской АЭС (оз. Имандра) / Д.Б. Денисов, Н.А. Кашулин // Труды КНЦ РАН: прикладная экология Севера, 3/2013 (16). С. 68-94.

8. Денисов Д.Б., Даувальтер В.А., Кашулин Н.А. Диатомовые комплексы донных отложений озера Имандра в зоне влияния подогретых вод Кольской 
АЭС // Тр. Кольского научного центра РАН. Прикладная экология Севера. Апатиты: КНЦ РАН, 2015. № 9. С. 10-24.

9. Косова А.Л., Малышева М.Б., Денисов Д.Б. К методике камеральной обработки проб для диатомового анализа донных отложений // Матер.VII Всеpoc. совещания по изучению четвертичного периода. Т. 1. Апатиты; Спб, 2011. C. 294-296.

10. Моисеенко Т.И., Разумовский Л.В. Новая методика реконструкции катионно-анионного баланса в озерах (диатомовый анализ) // Докл. Академии наук. Т. 427. 2009. № 1. С. 132-135.

11. Новаковский А. Б. Обзор программных средств, используемых для анализа геоботанических данных // Растительность России. 2006. № 9. С. 86-95. 12. Померанцев А.Л. Метод Главных Компонент (РСА). 2008. 18 с.

13. Руководство по методам химического анализа морских вод Л.: Гидрометеоиздат. 1977. $208 \mathrm{c}$.

14. Сиделев, С.И. Математические методы в биологии и экологии: введение в элементарную биометрию: учебное пособие / С.И. Сиделев; Яросл. гос. ун-т им. П.Г. Демидова. Ярославль : ЯрГУ, 2012. 140 с.

15. Сладечек В. Общая биологическая схема качества воды // Санитарная и техническая гидробиология: материалы I Съезда Всесоюз. гидробиол. о-ва. - М.: Наука, 1967. С. 26-31.

16. Шаров А.Н. Фитопланктон водоемов Кольского полуострова. Петрозаводск: Карельский научный центр РАН, 2004. 113 с.

17. Czekanowski J. Zur differential Diagnose der Neandertalgruppe // Korrespbl. Dtsch

18. Ges. Anthropol. 1909. Bd 40. 44- 47 pp.

19. Dice L.R. Measures of the amount of ecological association between species // Ecology. 1945. V. 26. № 3. 297- 302 pp.

20. Jaccard P. Distribution de la flore alpine dans le Bassin des Dranses et dans quelques regions voisines // Bull. Soc. Vaudoise sci. Natur. 1901. V. 37. Bd. 140. 241-272 pp.

21. Sörensen T. A method of establishing groups of equal amplitude in plant sociology based on similarity of species content // Kongelige Danske Videnskabernes Selskab. Biol. krifter. Bd V. № 4. 1948. P. 1-34.

22. Shannon C.E., Weaver W. The Mathematical Theory of Communication. Urbana: Univ. Illinois Press, 1949. 117 p.

23. Simpson, E. H. Measurement of species diversity. Nature, 1949. 163: 688 p.

24. Standard method for examination for water and wastewater. USA. 1975. $1195 \mathrm{p}$.

25. Szymkiewicz D. Une contribution statistique a la géographie floristique // Acta Soc. Bot. Polon. 1934. T. 34. № 3. 249-265 pp. 